\title{
Nutritional availability to rats of selenium in four seafoods: crab (Callinectes sapidus), oyster (Crassostrea virginica), shrimp (Penaeus duorarum) and Baltic herring (Clupea harengus)
}

\author{
BY MARJA MUTANEN \\ Department of Nutrition, University of Helsinki, Viiki, SF-00710 Helsinki 71, Finland \\ AND PEKKA KOIVISTOINEN \\ Department of Food Chemistry and Technology, University of Helsinki, Viiki, \\ SF-00710 Helsinki 71, Finland \\ AND VIRGINIA C. MORRIS AND ORVILLE A. LEVANDER* \\ US Department of Agriculture, Agricultural Research Service, \\ Beltsville Human Nutrition Research Center, Vitamin and Mineral Nutrition Laboratory, \\ Beltsville, Maryland 20705, USA
}

(Received 23 May 1985 - Accepted 18 September 1985)

1. The present study was conducted to determine the biological availability to rats of the selenium in four high-Se seafoods: crab (Callinectes sapidus), oyster (Crassostrea virginica), shrimp (Penaeus duorarum) and Baltic herring (Clupea harengus).

2. Weanling male rats were fed on a Se-deficient Torula yeast diet for 4 weeks followed by either continued depletion or repletion for 4 weeks with $0.05,0.1$ or $0.2 \mu \mathrm{g} \mathrm{Se}$ as selenite/g, or 0.1 or $0.2 \mu \mathrm{g}$ Se as freeze-dried cooked test food/g. Plasma and liver Se levels or glutathione peroxidase (EC 1.11.1.9; GSH-Px) activities were used as indicators of body Se status.

3. Except for oysters, the biological availability of Se in all these seafoods was close to that of selenite (selenite $100 \%$ ) when the criterion used was either plasma Se level or plasma GSH-Px activity.

4. By the criterion of increased liver Se level of restored hepatic GSH-Px activity, only herring-Se had a biological availability comparable to that of selenite-Se under all conditions tested, whereas crab-Se and oyster-Se were distinctly inferior in this regard.

5. Increasing the amount of crab-Se, oyster-Se or shrimp-Se supplied in the diet from 0.1 to $0.2 \mu \mathrm{g} / \mathrm{g}$ changed the apparent availability (\%) of Se for hepatic GSH-Px restoration from 38 to 78,22 to 53 and 57 to 90 respectively.

6. The present study demonstrates that the availability of Se in certain foods is a function of the criterion chosen, the level of Se supplied in the diet, and possibly other unknown interacting dietary factors.

One of the main sources of selenium in the diet is seafood. For this reason, the nutritional biological availability of Se in seafoods has been studied extensively, and several authors have shown that the Se in seafoods has a low availability (Cantor et al. 1975; Gabrielsen \& Opstvedt, $1980 \mathrm{~b}$; Douglass et al. 1981 ; Alexander et al. 1983). Thus, seafoods, although containing high levels of Se, would be of limited value as a source of Se in nutrition. Crab (Callinectes sapidus), oyster (Crassostrea virginica), shrimp (Penaeus duorarum) and Baltic herring (Clupea harengus) are four seafoods which are known to contain high levels of Se (Morris \& Levander, 1970; Koivistoinen, 1980). In Finland the mean dietary Se intake is very low, being only about $30 \mu \mathrm{g} / \mathrm{d}$ (Koivistoinen, 1980), and Baltic herring is thought to contribute an appreciable amount of that intake. The purpose of the present study was to investigate the nutritional biological availability of Se in these seafoods. 
Table 1. Composition of the diets* $(\mathrm{g} / \mathrm{kg})$

\begin{tabular}{lcc}
\hline \hline Added dietary selenium $(\mu \mathrm{g} / \mathrm{g}) \ldots$ & $0 \cdot 1$ & $0 \cdot 2$ \\
\hline Torula yeast & 300 & 300 \\
Basal & $-70 \cdot 6$ & $81 \cdot 2$ \\
Crab† (Callinectes sapidus) & $23 \cdot 9$ & $47 \cdot 9$ \\
Oyster (Crassostrea virginica) & $46 \cdot 7$ & $93 \cdot 5$ \\
Shrimp (Penaeus duorarum) & $91 \cdot 0$ & $182 \cdot 0$ \\
Baltic herring (Clupea harengus) & 35 & 35 \\
Salt mix $\$$ & 10 & 10 \\
Vitamin mix & 50 & 50 \\
Maize oil & to total 1000 & to total 1000 \\
Sucrose &
\end{tabular}

* All diets contained $100 \mathrm{mg}$ vitamin $\mathrm{E}$ as DL- $\alpha$-tocopheryl acetate, $3 \mathrm{~g}$ DL-methionine and $2.25 \mathrm{~g}$ choline $/ \mathrm{kg}$ diet.

$\dagger$ Test foods were prepared as for human consumption, then freeze-dried.

‡ Williams-Briggs Salt Mix, Teklad Test Diets, Harlan Industries, Inc., Madison, WI 53711. The salt mix was adjusted to contain graded levels of $\mathrm{Se}$ as $\mathrm{Na}_{2} \mathrm{SeO}_{3}$ in the standard diets.

$\$$ Supplies (mg/kg diet): thiamin hydrochloride $3 \cdot 75$, riboflavin $7 \cdot 5$, pyridoxine hydrochloride $3 \cdot 6$, niacin 45 , calcium pantothenate 24 , cyanocobalamin 0.015 , menadione 0.3 , folic acid 0.5 , biotin 0.2 , retinyl palmitate 6.6 , ergocalciferol $0 \cdot 025$.

\section{MATERIALS AND METHODS}

Weanling male Fischer 344 rats were housed in pairs in hanging stainless-steel wire cages and had free access to food and water. Rats were weighed weekly throughout the experiments. In order to bring the rats to the same baseline Se status, they were first fed on a Se-deficient Torula yeast basal diet (Table 1), supplemented with vitamin $\mathrm{E}$ and methionine, for 4 weeks. The basal diet contained $0.02 \mu \mathrm{g} \mathrm{Se} / \mathrm{g}$ or less as determined by fluorometric analysis (Hoffman et al. 1968). They were then continued on the basal diet or fed on the basal diet supplemented with graded levels of Se as sodium selenite $(0.05,0 \cdot 1$ or $0.2 \mu \mathrm{g} / \mathrm{g}$ ) or with 0.1 or $0.2 \mu \mathrm{g} \mathrm{Se} / \mathrm{g}$ as test foods (crab, oyster, shrimp or Baltic herring) (Table 1) for an additional 4 weeks. The four seafoods studied were purchased from a local food chain: crab, oyster and shrimp in Maryland, USA, and Baltic herring fillets in Finland. Before freeze-drying and grinding, all the test foods were prepared as for human consumption. Crab and shrimp were cooked in water and oysters in their own juice. Baltic herring fillets were baked in the oven at $250^{\circ}$ for $10 \mathrm{~min}$. The Se content of freeze-dried crab, oyster, shrimp and Baltic herring after cooking was, by analysis, 2.5, 4.2, $2 \cdot 1$ and $1 \cdot 1 \mu \mathrm{g} \mathrm{Se} / \mathrm{g}$ respectively. The biological availability of the Se in these seafoods was studied in two different experiments, crab and oyster in Expt 1 and shrimp and Baltic herring in Expt 2.

Rats were killed under diethyl ether anaesthesia by exsanguination. Whole blood was collected from the abdominal aorta into tubes containing $0 \cdot 1$ vol. trisodium citrate $(32 \mathrm{~g} / \mathrm{l})$ and centrifuged at $4^{\circ}$ and $2500 \mathrm{~g}$ for $15 \mathrm{~min}$. Plasma samples were frozen at $-20^{\circ}$ for Se determination and glutathione peroxidase (EC 1.11.1.9; GSH-Px) assay.

The livers were removed immediately after blood was withdrawn, rinsed with cold 0.15 M-potassium chloride, weighed, and homogenized in 4 vol. $\mathrm{KCl}$ in a glass Potter-Elvehjem homogenizer with a Teflon pestle. Crude homogenate $(10 \mathrm{ml})$ was frozen at $-20^{\circ}$ for Se determination. The remainder of the homogenate was centrifuged at $4^{\circ}$ and $9900 \mathrm{~g}$ for 15 $\min$. The postmitochondrial supernatant fraction was decanted and centrifuged at $4^{\circ}$ and $105000 \mathrm{~g}$ for $1 \mathrm{~h}$. The postmicrosomal supernatant fraction was removed and frozen at $-20^{\circ}$ for liver GSH-Px assay. The coupled method of Paglia \& Valentine (1979) was used for 


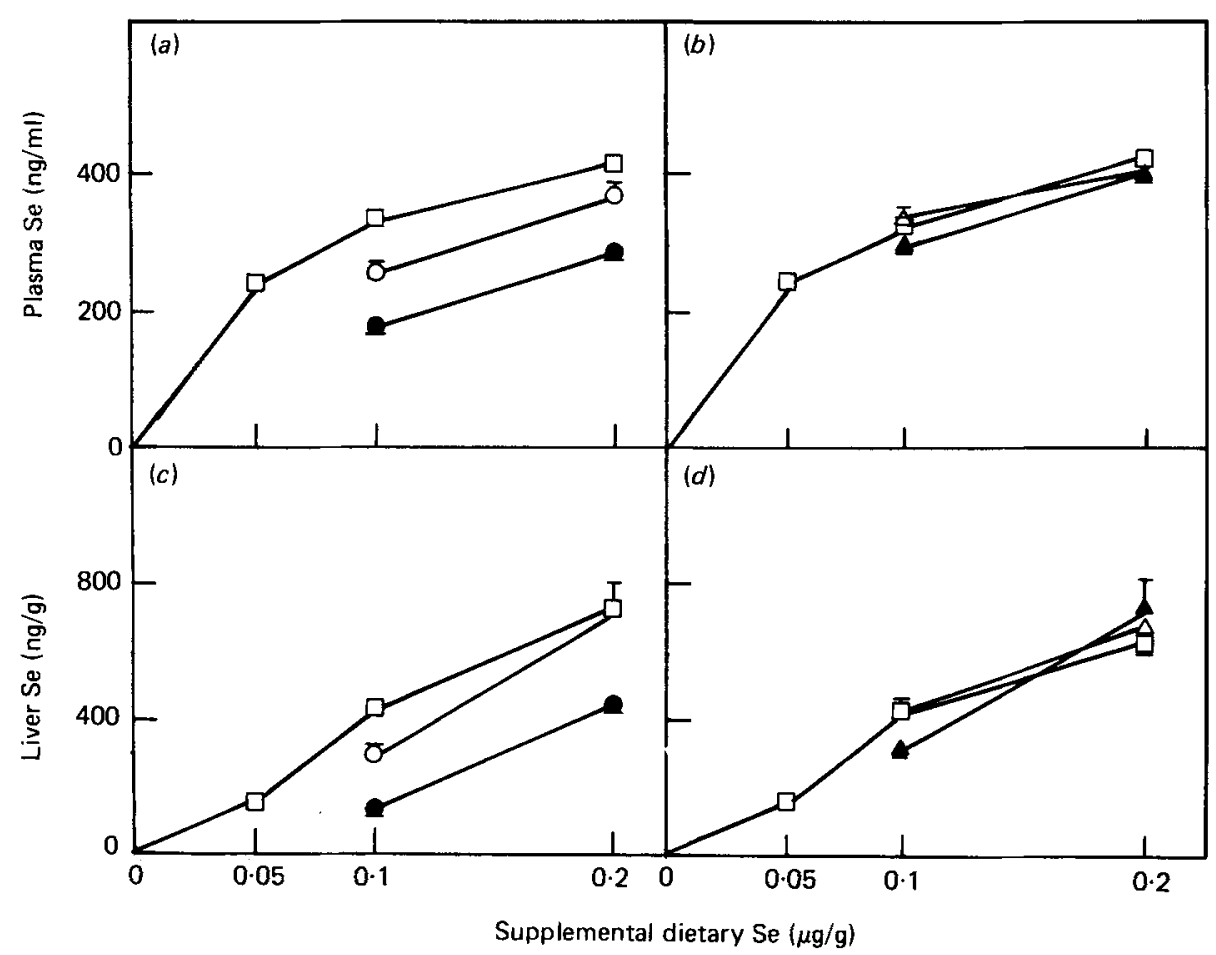

Fig. 1. Effect of various selenium sources on plasma $(a, b)$ and liver $(c, d)$ Se levels of Se-depleted rats. ( $\square$ ), Selenite; (O), crab (Callinectes sapidus); (О), oyster (Crassostrea virginica); (A), shrimp (Penaeus duorarum); $(\triangle)$, Baltic herring (Clupea harengus). Values in $(a)$ and $(c)$ are from Expt 1 , and those in $(b)$ and $(d)$ from Expt 2. Values are means, with their standard errors represented by vertical bars, for five to six rats.

automated determination (McAdam et al. 1984) of GSH-Px activity in plasma and liver supernatant fractions. The substrate was $0.30 \mathrm{~mm}$-tert-butyl-hydroperoxide. GSH-Px activity is expressed as $\mathrm{mU} / \mathrm{mg}$ protein, i.e. nmol NADPH oxidized/min per $\mathrm{mg}$ protein. Tissue Se levels were analysed by a double-isotope-dilution technique combined with a gas-liquid chromatographic-mass spectrometric analysis (Reamer \& Veillon, 1981).

The biological availability of Se was assessed by the ability of Se to restore hepatic and plasma Se levels and GSH-Px activities. The availability of Se was calculated with the point-slope technique (Cantor et al. 1975) as the percentage of the response generated by the test diet compared with that of the standard diet. In these calculations the standard curves were smoothed by linear regression and the regression equation was used to calculate biological availability percentages.

\section{RESULTS}

The effects of the various dietary Se sources on plasma and liver Se levels are shown in Fig. 1 . The most significant observation is that the ability of oyster-Se to raise both plasma and liver Se levels was considerably less than that of the other seafoods studied. Another significant feature concerning liver Se levels was the dependence of Se availability in crab and oyster on the dietary Se level. The results cannot be explained by the differences in the growth rates of the rats, because there were no significant differences $(P \geqslant 0 \cdot 05$, KolmogorovSmirnov test) among experimental groups after 4 weeks of repletion (Table 2). 
Table 2. Expts 1 and 2. Body-weights of the rats after 4 weeks of repletion*

(Mean values with their standard errors)

\begin{tabular}{|c|c|c|c|c|c|}
\hline \multirow[b]{3}{*}{ Diet } & \multirow{3}{*}{$\begin{array}{c}\text { Added } \\
\text { dietary } \\
\text { selenium } \\
(\mu \mathrm{g} / \mathrm{g})\end{array}$} & \multicolumn{4}{|c|}{ Body-wt (g) } \\
\hline & & \multicolumn{2}{|c|}{ Expt 1} & \multicolumn{2}{|c|}{ Expt 2} \\
\hline & & Mean & SE & Mean & $\mathbf{S E}$ \\
\hline Basal & 0 & 215 & 8 & 221 & 6 \\
\hline \multirow[t]{3}{*}{ Basal $+\mathrm{Na}_{2} \mathrm{SeO}_{3}$} & 0.05 & 212 & 5 & 212 & 6 \\
\hline & $0 \cdot 1$ & 216 & 6 & 224 & 8 \\
\hline & $0 \cdot 2$ & 217 & 9 & 230 & 3 \\
\hline \multirow[t]{2}{*}{ Crab (Callinectes sapidus) } & $0 \cdot 1$ & 227 & 7 & - & - \\
\hline & $0 \cdot 2$ & 220 & 4 & - & - \\
\hline \multirow[t]{2}{*}{ Oyster (Crassostrea virginica) } & $0 \cdot 1$ & 228 & 10 & - & 一 \\
\hline & $0 \cdot 2$ & 211 & 7 & - & - \\
\hline \multirow[t]{2}{*}{ Shrimp (Penaeus duorarum) } & $0 \cdot 1$ & - & - & 230 & 8 \\
\hline & 0.2 & - & - & 207 & 13 \\
\hline \multirow[t]{2}{*}{ Baltic herring (Clupea harengus) } & $0 \cdot 1$ & - & - & 226 & 6 \\
\hline & $0 \cdot 2$ & - & - & 236 & 11 \\
\hline
\end{tabular}

* Before Se repletion, rats were given a Se-deficient diet for 4 weeks.

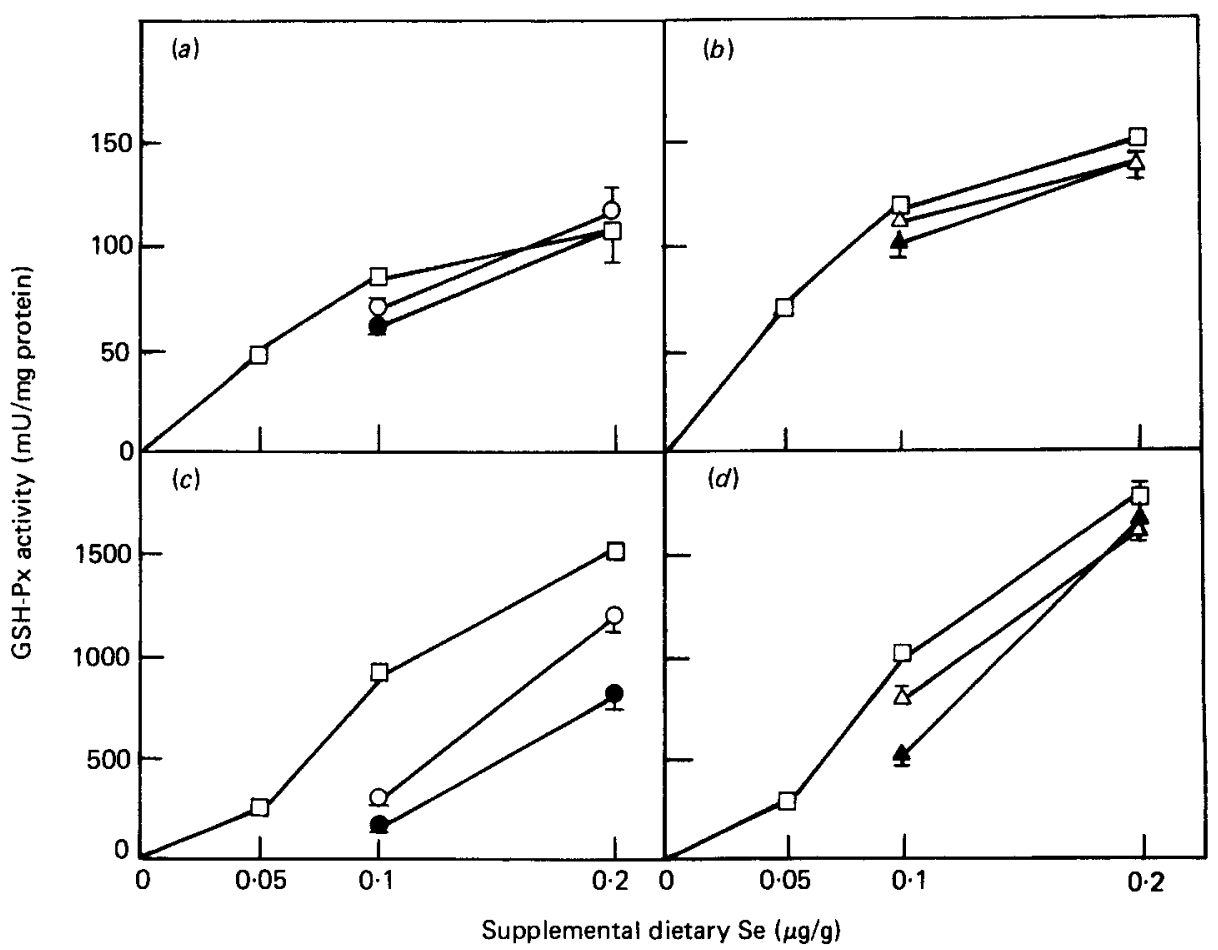

Fig. 2. Effect of various selenium sources on plasma $(a, b)$ and liver $(c, d)$ glutathione peroxidase $(E C$ 1.11.1.9; GSH-Px) activity of Se-depleted rats. ( $\square$ ), Selenite; (O), crab (Callinectes sapidus); (O), oyster (Crassostrea virginica); (A), shrimp (Penaeus duorarum); $(\triangle)$, Baltic herring (Clupea harengus). Values in $(a)$ and $(c)$ are from Expt 1 , and those in $(b)$ and $(d)$ from Expt 2. Values are means, with their standard errors represented by vertical bars, for five to six rats. 
Table 3. Percentage biological availability of food selenium sources relative to selenite $(100 \%)$ for glutathione peroxidase (EC 1.11.1.9, GSH-PX) induction and elevation of Se in plasma and liver of Se-depleted rats

(Mean values with their standard errors for five to six samples)

\begin{tabular}{|c|c|c|c|c|c|c|c|c|}
\hline \multirow{3}{*}{$\begin{array}{c}\text { Food Se source and Se } \\
\text { level given }(\mu \mathrm{g} / \mathrm{g})\end{array}$} & \multicolumn{4}{|c|}{ Plasma } & \multicolumn{4}{|c|}{ Liver } \\
\hline & \multicolumn{2}{|c|}{$\mathrm{Se}$} & \multicolumn{2}{|c|}{ GSH-Px } & \multicolumn{2}{|c|}{$\mathrm{Se}$} & \multicolumn{2}{|c|}{ GSH-Px } \\
\hline & Mean & SE & Mean & SE & Mean & SE & Mean & SE \\
\hline \multicolumn{9}{|l|}{ Expt 1} \\
\hline \multicolumn{9}{|l|}{ Crab (Callinectes sapidus) } \\
\hline $0 \cdot 1$ & 89 & 6 & 105 & 3 & 76 & 3 & 38 & 4 \\
\hline 0.2 & 80 & 3 & 100 & 8 & 99 & 9 & 78 & 9 \\
\hline \multicolumn{9}{|l|}{ Oyster (Crassostrea virginica) } \\
\hline 0.1 & 62 & 2 & 92 & 2 & 36 & 1 & 22 & 2 \\
\hline 0.2 & 61 & 2 & 91 & 16 & 60 & 4 & 53 & 5 \\
\hline \multicolumn{9}{|l|}{ Expt 2} \\
\hline \multicolumn{9}{|l|}{ Shrimp (Penaeus duorarum) } \\
\hline 0.1 & 103 & 3 & 105 & 3 & 89 & 4 & 57 & 7 \\
\hline 0.2 & 83 & 3 & 85 & 3 & 113 & 11 & 90 & 4 \\
\hline \multicolumn{9}{|l|}{ Baltic herring (Clupea harengus) } \\
\hline 0.1 & 118 & 2 & 118 & 2 & 126 & 4 & 88 & 9 \\
\hline 0.2 & 83 & 2 & 84 & 3 & 102 & 8 & 91 & 10 \\
\hline
\end{tabular}

The responses in plasma and liver GSH-Px activity are shown in Fig. 2. The ability of crab- and oyster-Se to restore plasma GSH-Px activity was superior to their ability to elevate plasma Se level, whereas herring-Se and shrimp-Se have similar abilities for increasing either plasma GSH-Px activity or plasma Se level. On the other hand, the ability of these seafoods to restore liver GSH-Px activity seems to be dependent on the level of Se supplied in the diet. For example, the relative ability of crab- and oyster-Se to restore liver GSH-Px activity when given at the $0.1 \mu \mathrm{g} / \mathrm{g}$ level was only about half that when given at the $0.2 \mu \mathrm{g} / \mathrm{g}$ level. Moreover, the availability of Se in shrimp was comparable to that in herring when both foods were given at $0.2 \mu \mathrm{g} \mathrm{Se} / \mathrm{g}$, but shrimp-Se was only two-thirds as active as herring-Se when both were given at $0 \cdot 1 \mu \mathrm{g} \mathrm{Se} / \mathrm{g}$.

The relative biological availability of the Se in the seafoods tested for elevation of Se level and GSH-Px activity in plasma and liver is summarized in Table 3. As shown, the percentage Se biological availability varied among the four different criteria used. According to plasma GSH-Px activity, the Se availability from all these seafoods was good and, with the exception of oyster-Se, this was also true in the case of plasma Se. On the other hand, when using liver Se or liver GSH-Px activity as an indicator of body Se status, only the availability of Se from Baltic herring was consistently good. According to liver GSH-Px activity, the Se in shrimp was somewhat less available and that in crab and oyster was considerably less available than that in selenite.

\section{DISCUSSION}

The biological availability of Se from the seafoods studied was assessed in two separate experiments, but the similarity of the standard curves in both experiments indicates that the results obtained are comparable and that the assay is reproducible. The results demonstrate that the biological availability of Se in different foods may be a complex function of the criterion studied, the level of dietary Se and other dietary factors. 
In studies of Se availability, the criteria of body Se status vary (Cantor et al. 1975; Douglass et al. 1981; Alexander et al. 1983; Gabrielsen \& Opstvedt, 1980 a) and the general validity of the availability values obtained depends on the extent to which the criterion used is a true reflection of Se status in the body. The criteria used in our study were liver and plasma Se level and GSH-Px activity. The liver has the largest labile pool of Se in the body and undergoes the greatest changes in Se level and GSH-Px activity when dietary Se intake is altered (Levander et al. 1983). Thus, these hepatic criteria are presumably valid indices of an important short-term body pool of Se even though they may not always reflect the status of other significant, longer-term body Se pools, such as the skeletal muscle (Levander, 1983). Of the seafoods studied, the liver values from crab-Se support the concept that even if the Se from a certain food reaches the tissues, it may not necessarily be efficiently incorporated into the active site of GSH-Px (Cantor et al. 1975; Chansler et al. 1983).

The liver GSH-Px values from crab-, oyster-, and shrimp-Se support earlier findings (Cantor et al. 1975) that the higher the Se content of the diet, the higher the relative availability of the Se. However, the diets in the present study were not equal in terms of nutrients other than Se, which may partly explain the differences. For example, a positive relation has been shown between the dietary protein content and the availability of Se to rats (Zhou et al. 1983). Moreover, the dietary level of methionine may also influence the utilizability of Se (Sunde et al. 1981). The protein content of our diets was higher at the $0.2 \mu \mathrm{g} \mathrm{Se} / \mathrm{g}$ level than at the $0 \cdot 1 \mu \mathrm{g} / \mathrm{g}$ level, and the highest availability of Se was observed in the herring diet which also contained the most protein.

Since the origin of Se and GSH-Px activity in the plasma is not known, the validity of these criteria of body Se status is uncertain. Estimates of Se availability derived from measurements of plasma Se and plasma GSH-Px activity should be considered with caution because the standard curves generated by such values are not a linear function of the level of Se supplied in the diet (Figs. 1 and 2). Rather, the standard curves plateau above $0 \cdot 1 \mu \mathrm{g}$ $\mathrm{Se} / \mathrm{g}$ and this phenomenon does not comply with the requirement for fundamental and statistical validity (Finney, 1971).

The over-all results obtained in the present study differ from earlier findings concerning the biological availability of Se in seafoods. Especially interesting is the relatively high availability of Se in Baltic herring. Gabrielsen \& Opstvedt (1980 b) reported 34 and $48 \%$ availability values for the Se in fish meal to chicks, and Douglass et al. (1981) and Alexander et al. (1983) showed the availability of Se to rats to be as low as $22-57 \%$ from different tuna (Thunnus alalunga) products as compared with selenite. Various factors may interfere with the utilization of dietary Se (Combs \& Scott, 1974; Lane et al. 1979; Yasumoto et al. 1979) but, in the case of seafood, of particular interest is the possible interaction of Se with heavy metals (Levander \& Cheng, 1980). Depending on the type of seafood and the degree of water contamination where the samples are collected, the concentration of these metals may vary greatly between samples. The great difference in mercury content of Baltic herring and shrimp $(0.037$ and $0.084 \mu \mathrm{g} / \mathrm{g}$ respectively) compared with that in tuna fish $(0.42 \mu \mathrm{g} / \mathrm{g}$; Koivistoinen, 1980) may partly explain the difference between earlier findings and our results. This suggestion is supported by evidence concerning a $\mathrm{Hg}-\mathrm{Se}$ interaction (Ganther \& Sunde, 1974). The other explanation for the discrepancies between studies is purely methodological. The possibility that Se availability as determined in different studies is influenced by variation in the dietary Se level and type of diet given, as well as by variation in the indicators used to assess body Se status, cannot be excluded.

The work reported here emphasizes once again the need for information about Se availability in foods and also emphasizes the importance of developing a valid assay which would make possible the comparison of availability results from different studies.

M.M. was a Fellow of the W. K. Kellogg Foundation during the academic year 1983-4. 


\section{REFERENCES}

Alexander, A. R., Whanger, P. D. \& Miller, L. T. (1983). Journal of Nutrition 113, 196-204.

Cantor, A. H., Scott, M. L. \& Noguchi, T. (1975). Journal of Nutrition 105, 96-105.

Chansler, M. W., Morris, V. C. \& Levander, O. A. (1983). Federation Proceedings 42, 927.

Combs, G. F. Jr \& Scott, M. L. (1974). Journal of Nutrition 104, 1297-1303.

Douglass, J. S., Morris, V. C., Soares, J. H. Jr \& Levander, O. A. (1981). Journal of Nutrition 111, $2180-2187$.

Finney, D. J. (1971). Statistical Method in Biological Assay, 2nd ed. London: Griffin.

Gabrielsen, B. O. \& Opstvedt, J. (1980a). Journal of Nutrition 110, 1089-1095.

Gabrielsen, B. O. \& Opstvedt, J. (1980 b). Journal of Nutrition 110, 1096-1 100.

Ganther, H. E. \& Sunde, M. L. (1974). Journal of Food Science 39, 1-5.

Hoffman, I., Westerby, R. J. \& Hidiroglou, M. (1968). Journal of the Association of Official Analytical Chemists 51, 1039-1042.

Koivistoinen, P. (1980). Acta Agrictulturae Scandinavica Suppl. 22.

Lane, H. W., Shirley, R. L. \& Cerda, J. J. (1979). Journal of Nutrition 109, 444-452.

Levander, O. A. (1983). Federation Proceedings 42, 1721-1725.

Levander, O. A. \& Cheng, L. (1980). Annals of the New York Academy of Sciences 335, 1-376.

Levander, O. A., De Loach, D. P., Morris, V. C. \& Moser, P. B. (1983). Journal of Nutrition 113, 55-64.

McAdam, P. A., Morris, V. C. \& Levander, O. A. (1984). Federation Proceedings 43, 867.

Morris, V. C. \& Levander, O. A. (1970). Journal of Nutrition 100, 1383-1388.

Paglia, D. E. \& Valentine, W. N. (1979). Journal of Laboratory and Clinical Medicine 70, 158-168.

Reamer, D. C. \& Veillon, C. (1981). Analytical Chemistry 53, 2166-2169.

Sunde, R. A., Gutzke, G. E. \& Hoekstra, W. G. (1981). Journal of Nutrition 111, 76-86.

Yasumoto, K., Iwamimi, K. \& Yoshida, M. (1979). Journal of Nutrition 109, 760-766.

Zhou, R., Sun, S., Zhai, F., Man, R., Guo, S., Wang, H. \& Yang, G. (1983). Acta Nutrimenta Sinica 5, $137-144$. 